\title{
THE PERFORMANCE OF MAIZE CROP DURING ACID AMELIORATION WITH ORGANIC RESIDUES IN SOILS OF MTWARA, TANZANIA
}

\author{
AE Majule and JO Omollo \\ Institute of Resource Assessment (IRA), University of Dar es Salaam, \\ P.O. Box 35063, Dar es Salaam, Tanzania. amajule@ira.udsm.ac.tz
}

\begin{abstract}
This study evaluated acid ameliorative potential and their effects on maize growth of four organic residues namely wild spikenard, cordia, cowpea and pigeon peas through incubations with or without sulphur. This was done in order to recommend potential organic residue source that could ameliorate soil acidity associated with sulphur dusting. Increased levels of sulphur in the soils reduced the growth and dry matter yields of maize due to intense acidification while maize growth and dry matter yields in soils which organic residues were incorporated was enhanced. Enhancement in maize performance may be a result of reduced soil acidity due to ameliorative effects of residues which was directly related to the alkalinity of the organic residues. Pigeon pea and cordia residues, which had higher alkalinity, resulted in a higher acid amelioration compared to senescent cowpea and wild spikenard, which had lower alkalinity. The performance of maize grown in respective soil incorporated with the organic residues followed the same pattern. The finding suggests different acid ameliorating potential of residues, pigeon peas and cordia being the most effective. The residues are therefore recommended in cashew farming system in order to improve soil fertility to enhance crop production.
\end{abstract}

\section{INTRODUCTION}

Cashewnut (Anarcardium occidentale L.) is one of major perennial cash crops in Tanzania, particularly in the Southern coastal areas. Cashewnut is mostly affected by powdery mildew (PMD) caused by Oidium anarcardii (Martin et al. 1997). Sulphur is so far the most suitable chemical for controlling PMD (Smith et al. 1995). Despite elemental sulphur effectiveness in PMD control, long term field experiments indicated that $\mathrm{S}$ could have serious environmental consequences due to acidification as a result of $\mathrm{S}$ oxidation in the soil (Majule et al. 1997). In the long run, acidification has been reported to reduce productivity of annual food crops such like the ones that are commonly intercropped with cashews (Ngatunga et al. 2001).

Research has shown that one of the potential measures of improving acidic soils is the application of alkaline organic residues (Majule 1999). Potential alkalinity (PA) of plant residue is a measure of the ability of residues to ameliorate soil acidity and it is expressed as mmol $\mathrm{OH}^{-} / \mathrm{kg}$ of organic residue. It is partitioned into two major parts namely available alkalinity and non available alkalinity (Sakala 1998, Majule 1999). Available alkalinity (AA) is a portion of PA, which is attributed to the readily soluble fraction of the organic anions while non available alkalinity (NAA) is attributed to organic anions that do not readily ionise. This becomes more significant with time as the residues undergo decomposition (Pocknee and Sumner 1997). Soluble available alkalinity is an active fraction responsible for the immediate increase in soil $\mathrm{pH}$ while non soluble alkalinity fractions has long term effects in amelioration of soil acidity (Sakala 1998, Majule 1999). This study therefore characterised four selected organic residue sources namely, wild spikenard (Hyptis suaveolens), cordia (Cordia sp.), cowpea (Vigna unguiculata) and pigeonpea (Cajanus cajan) and evaluated their influence on soil conditions, in particular the amelioration of soil $\mathrm{pH}$ as well as their effects on maize growth. 
Majule and Omolo - The performance of maize crop during acid amelioration ...

\section{MATERIALS AND METHODS}

The study area

The soil classified as Luvic arenosol (WRB; World Resource Base, 1988) by Majule (1999) used was sampled at the Agricultural Research Institute, Naliendele, Mtwara cashewnut fields, located about $12 \mathrm{~km}$ away from Mtwara town, Mtwara Region, while Cordia and wild spikenard residues were collected from Makukwe village in Tandahimba district, Mtwara Region.

\section{Soil characterization}

A composite soil sample was air dried and a portion was ground and passed through a $2 \mathrm{~mm}$ sieve for routine soil analysis. Soil $\mathrm{pH}$ was determined in $1: 2.5$ soil:water suspension using a $\mathrm{pH}$ meter (MacLean 1982). Available phosphorus (P) was extracted according to the Bray 1 method (Bray and Kurtz 1945) and then determined colorimetrically using the ascorbic acid method of Murphy and Rilley (1962). Total nitrogen was determined by macro-kjeldahl digestion method followed by distillation (Bremner and Mulvaney 1982). Organic carbon was determined by the method of Wakley-Black (Nelson and Sommers 1982). Exchangeable $\mathrm{Ca}^{2+}$ and $\mathrm{Mg}^{2+}$ from the ammonium acetate leachates were determined by atomic absorption spectrophotometer while exchangeable cations $\mathrm{K}^{+}$and $\mathrm{Na}^{+}$were determined by the flame spectrophotometer (Thomas, 1982). Particle size distribution was determined by the hydrometer method (Gee and Bauder, 1986).

\section{Characterisation of plant residues}

Four potential plant residues used in this study. These were cowpea (Vigna unguiculata) and pigeonpea (Cajanus cajan) leaves, and steams and two local shrubs whose local names are "mjini" or wild spikenard (Hyptis suaveolens) and "mtapuchi" Cordia (Cordia sp.). The plant samples were cut to small pieces and ground to pass through a $0.5 \mathrm{~mm}$ sieve using a Tecator 1093 Cyclotec sample mill. The plant samples were wet digested using mixture of $\mathrm{HNO}_{3}$ and $\mathrm{H}_{2} \mathrm{O}_{2}$ as outlined by Jones and Case (1990) for determination of cations. calcium and magnesium concentrations were determined using AAS while $\mathrm{K}$ and $\mathrm{Na}$ were determined by using flame spectrophotometer. Total $\mathrm{N}$ was determined by following the procedure by Rowell (1994) and total P was determined by the ascorbic acid-molybdate blue method (Murphy and Riley 1962). Sulphur was determined by the turbidimetric reagent procedure as outlined by Moberg (2000) while chloride was measured in the extract by using AAS by following a procedure outlined by Zall et al (1956). Organic carbon was determined by the Wakley-Black method (Nelson and Sommers 1982).

\section{Residue alkalinities}

Determination of PA involved measurement of excess base cations. This involved taking sum of cations $\left(\mathrm{Ca}^{2+}+\mathrm{Mg}^{2+}+\mathrm{K}^{+}+\mathrm{Na}^{+}\right)$less sum of anions $\left(\mathrm{SO}_{4}{ }^{2-}+\mathrm{H}_{2} \mathrm{PO}_{4}{ }^{-}+\mathrm{Cl}^{-}\right)$contained in residue source. The cations and anions used were determined by the methods described early on this section (Pierre and Banwart 1973). The available alkalinity (AA), soluble available alkalinity (SAA) were determined by the method described by Sakala (1998) and Majule (1999). Non soluble available alkalinity (NSAA) was found by calculating the difference between AA and SAA. The non available alkalinity (NAA) was calculated by taking the difference between the PA and AA.

\section{Pot experiment}

A mixture of soil and sulphur was prepared by thoroughly mixing $0.576 \mathrm{~g}$ of elemental $\mathrm{S}$ with $20 \mathrm{~g}$ soil. The contents were then transferred into $20 \mathrm{ml}$ capped plastic bottles and further mixed. The mixture therefore contained $0.0288 \mathrm{~g} \mathrm{~S} / \mathrm{g}$ soil, which is equivalent to $72 \mathrm{~kg} \mathrm{~S} / \mathrm{ha}$, with the assumption that soil to a depth of $20 \mathrm{~cm}$ contains 2 500t soil/ha (Majule 1999). This is the amount of S estimated to be deposited on the soil when farmers spray elemental $\mathrm{S}$ at the rate of $90 \mathrm{~kg} \mathrm{~S} / \mathrm{ha}$ to control PMD in 
cashewnut trees. Thereafter $0,0.3,0.6$ or $3.0 \mathrm{~g}$ of the soil-S mixture $(0.0288 \mathrm{~g} \mathrm{~S} / \mathrm{g}$ soil) was mixed with $600 \mathrm{~g}$ soil and/or plant residues in pots, which were equivalent to field application rates of $0,36,72$ or $360 \mathrm{~kg}$
$\mathrm{S} /$ ha, respectively. The proportions applied were aimed to understand the effects of different amounts of $\mathrm{S}$ reaching the soil based on earlier report by Smith et al (1995).

Table 1: Treatments used in the pot experiment

\begin{tabular}{|c|c|c|c|c|}
\hline \multirow[t]{2}{*}{ Sulphur levels (S kg/ha) } & \multicolumn{4}{|l|}{$\mathrm{B}$} \\
\hline & 0 & 36 & 72 & 360 \\
\hline Plant Residues & & & & \\
\hline No residue $(\mathrm{R} 0)$ & $0, \mathrm{R} 0$ & $36, \mathrm{R} 0$ & $72, \mathrm{R} 0$ & $360, \mathrm{R} 0$ \\
\hline Wild spikenard (WS) & $0, \mathrm{WS}$ & 36 , WS & 72, WS & $360, \mathrm{WS}$ \\
\hline Cordia (CR) & $0, \mathrm{CR}$ & $36, \mathrm{CR}$ & $72, \mathrm{CR}$ & $360, \mathrm{CR}$ \\
\hline Cowpea (CP) & $0, \mathrm{CP}$ & $36, \mathrm{CP}$ & $72, \mathrm{CP}$ & $360, \mathrm{CP}$ \\
\hline Pigeonpea (PP) & $0, \mathrm{PP}$ & $36, \mathrm{PP}$ & $72, \mathrm{PP}$ & $360, \mathrm{PP}$ \\
\hline
\end{tabular}

Four grams of each of the residues were mixed with 600 grams soil portions equivalent to residue application of 16.67 $\mathrm{t} /$ ha. Maize plant was used as a test crop for a period of 30 days. The statistical design used was CRB with two factors namely amount of sulphur (A) with four levels and types of organic residue (B) (Table 1). The soil in the pots was watered to field capacity and so maintained for one week prior to sowing. Plant heights were determined by using a wooden ruler, from the ground level to the tallest leaf. This was carried out on the $10^{\text {th }}, 16^{\text {th }}$, and $30^{\text {th }}$ day after sowing. After 30 days, the plant shoots and roots were harvested, rinsed in distilled water to remove soil particles and then oven dried at $65^{\circ} \mathrm{C}$ to constant weight. Dry matter weights of the shoots and roots were then determined by using a portable weighing balance. The soil from the pots was analysed for soil $\mathrm{pH}$ (MacLean 1982). Sulphate-sulphur $\left(\mathrm{SO}_{4}{ }^{2-}-\mathrm{S}\right)$ was determined after 30 days using a method of Moberg (2000).

\section{Data analysis}

Statistical analysis was performed on soil $\mathrm{pH}$, maize plant height, shoot and root dry matter yields. The Duncan's New Multiple Range Test (DNMRT) was used for the separation of means within treatments (Gomez and Gomez 1984).

\section{RESULTS AND DISCUSSION \\ Physico-chemical characteristics of soil and organic residues \\ Soil properties}

Generally, the soil is strongly acid ( $\mathrm{pH}$ $5.30)$ with possible depletion of most major soil nutrient due to continuous cultivation. According to Landon (1991), total soil N $(0.4 \%)$, soil organic carbon $(0.5 \%)$, soil available phosphorus $(3.19 \mathrm{mgP} / \mathrm{kg}$ ) and extractable sulphate $(8.96 \mathrm{mgS} / \mathrm{kg})$ are all very low. Exchangeable $\mathrm{Ca}, \mathrm{Mg}$ and $\mathrm{K}$ are very low with values of $0.19,0.15$ and 0.09 cmol $(+) / \mathrm{kg}$ ), respectively (Euroconsult, 1989). The soil is characteristically sandy with $88 \%$ sand, $2 \%$ silt and $10 \%$ clay. The soil needs improvement in terms of matter, nitrogen and other major nutrients particularly available $\mathrm{P}$ if crop productivity is to be enhanced and sustained.

\section{Chemical properties of organic residues} Cowpea contained highest levels of OC. The tre n d w a s cowpea $>$ wild spikenard $>$ pigeonpea $>$ cordial (Table 2). Cordia had the highest amount of $\mathrm{N}$ while wild spikenard had the least. The $\mathrm{C}: \mathrm{N}$ ratio ranged from 10 in cordia to 25 in wild spikenard while cowpea and pigeonpea had intermediate values. Cordia contained highest amounts of basic cations, while 
Majule and Omolo - The performance of maize crop during acid amelioration ...

cowpea had the least amount. Generally $\mathrm{Ca}^{2+}$ and $\mathrm{K}^{+}$were the dominant cations while $\mathrm{Na}^{+}$ constituted a very small proportion, except for Cordia. Pigeonpea contained the highest amount of $\mathrm{P}$, while wild spikenard had the least amount of $P$.

Table 2: $\quad$ Element composition (\%) of organic residues

\begin{tabular}{lllll}
\hline \multirow{2}{*}{ Property } & \multicolumn{4}{c}{ Organic residue } \\
\cline { 2 - 5 } Elements (\%) & Cild Spikenard & Cordia & Cowpea & Pigeonpea \\
$\mathrm{Ca}$ & 0.53 & 0.61 & 0.48 & 1.11 \\
$\mathrm{Mg}$ & 0.26 & 0.24 & 0.22 & 0.39 \\
$\mathrm{~K}$ & 2.77 & 3.49 & 0.83 & 2.59 \\
$\mathrm{Na}$ & 0.04 & 1.09 & 0.01 & 0.04 \\
$\mathrm{P}$ & 0.15 & 0.30 & 0.23 & 0.33 \\
$\mathrm{~S}$ & 0.11 & 0.23 & 0.11 & 0.19 \\
$\mathrm{Cl}$ & 0.17 & 1.06 & 0.71 & 0.33 \\
\hline
\end{tabular}

High level of the basic cations $\left(\mathrm{Ca}^{2+}, \mathrm{Mg}^{2+}\right.$ and $\mathrm{K}^{+}$) implies not only better ability of the organic residues to improve soil fertility but also potential for amelioration/neutralisation of soil $\mathrm{pH}$ once incorporated into the soil (Majule 1999).

\section{Alkalinities of organic residues}

Different forms of alkalinity, as a measure of the potential of the organic residues in neutralising soil acidity, are summarised in Table 3 for the different organic residues.

Table 3: Forms of alkalinity of the organic residues

\begin{tabular}{|c|c|c|c|c|c|}
\hline Forms of Alkalinity & $\begin{array}{l}\text { Wild } \\
\text { Spikenard } \\
\quad \text { cmol }\end{array}$ & $\begin{array}{l}\text { Cordia } \\
\mathrm{OH}^{-} / \mathrm{kg} \\
\end{array}$ & $\begin{array}{l}\text { Senescent } \\
\text { Cowpea }\end{array}$ & $\begin{array}{l}\text { Young } \\
\text { cowpea }\end{array}$ & Pigeonpea \\
\hline Potential & 103.90 & 135.90 & 28.89 & $\mathrm{ND}$ & 117.48 \\
\hline Available & 16.60 & 22.40 & 7.80 & 28.20 & 36.60 \\
\hline Soluble Available & 12.85 & 17.75 & 6.50 & 22.50 & 31.75 \\
\hline Non Soluble Available & 38.50 & 4.65 & 1.30 & 5.70 & 4.85 \\
\hline Non Available & 87.31 & 113.54 & 21.09 & $\mathrm{ND}$ & 80.88 \\
\hline
\end{tabular}

Potential alkalinity values ranged from as

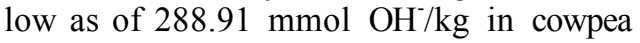
to as high of $1359.04 \mathrm{mmol} \mathrm{OH}^{-} / \mathrm{kg}$ in cordia. The order was; cowpea $<$ wild spikenard $<$ pigeonpea $<$ Cordia (Table 3 ). In terms of available alkalinity and its components that are soluble available and non soluble available alkalinities, pigeonpea contained the largest amount while senescent cowpea contained the lowest amount. The order of available alkalinity was; pigeonpea $>$ young cowpea $>$ Cordia $>$ wild spikenard $>$ senescent cowpea. Cordia had the highest amount of non available alkalinity while senescent cowpea had the lowest amount. The order was; Cordia $>$ wild spikenard $>$ pigeonpea $>$ senescent cowpea. The differences in alkalinity among the organic residues may be attributed to the plant species, with their accompanying differences in chemical composition. Similar results on alkalinity composition were reported by Pierre and Banwart (1973), Sakala (1998) and Majule (1999). 
Effects of organic residues incorporated in a Luvic arenosol on soil $\mathrm{pH}$

At all the sulphur levels, soil $\mathrm{pH}$ values were highest in soil to which wild spikenard was incorporated (Fig. 1) while it was lowest in soil without any residue added. In comparison with the other residue treatments, soil $\mathrm{pH}$ values were generally lowered by almost 0.5 unit in the $360 \mathrm{~kg}$ $\mathrm{S} /$ ha treatment, except the that treated with the wild spikenard residue. The high soil $\mathrm{pH}$ of the soil in which organic residues were incorporated than in the control indicates that the evaluated residues have the potential to ameliorate acid soils.

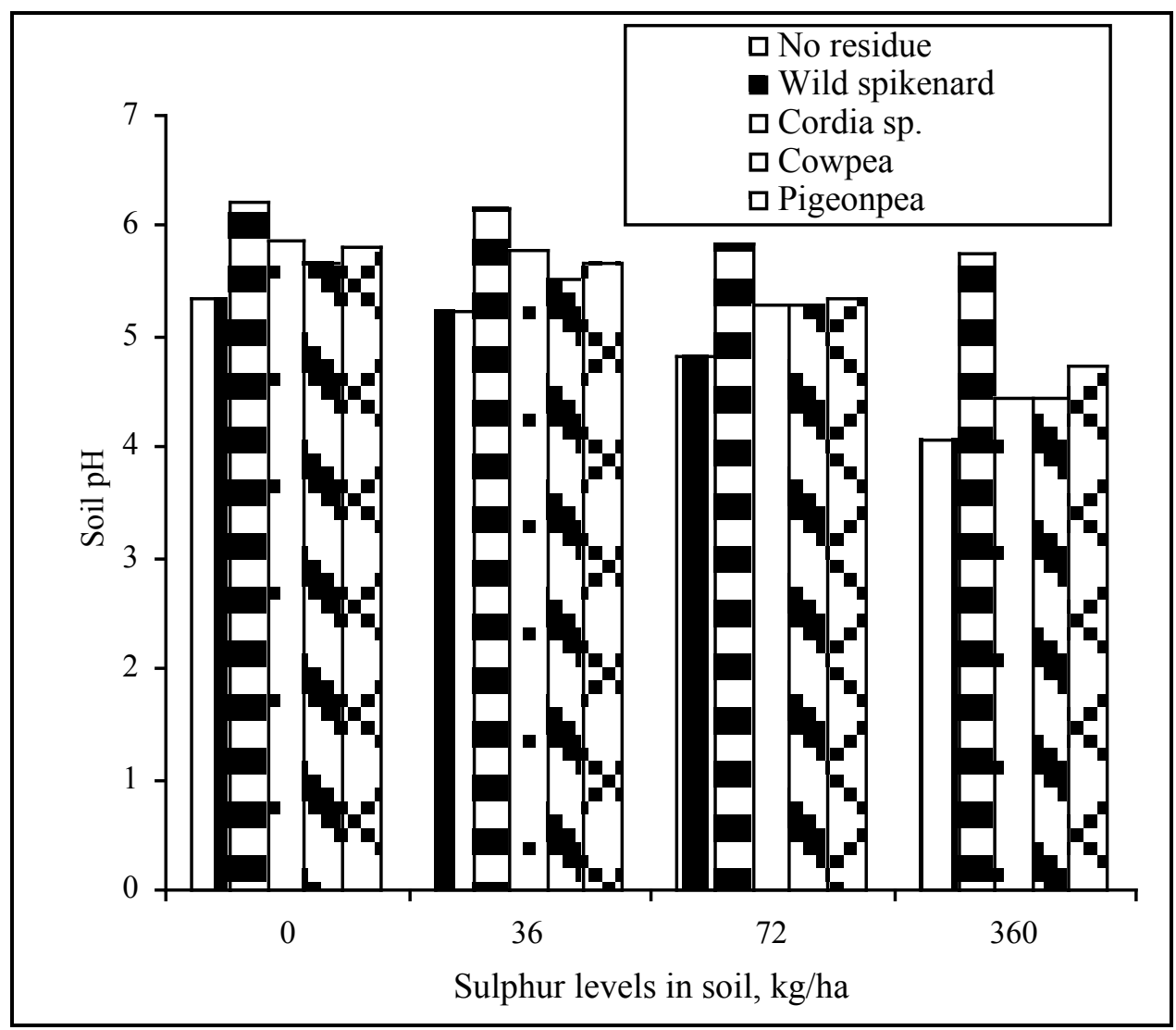

Figure 1: Effects of different types of organic residues incubated with sulphur in a Luvic arenosol on soil $\mathrm{pH}$ after 30 days of incubation and plant growth

The different soil $\mathrm{pH}$ values (Fig. 1) under different residues seem to be related to the residue alkalinity trends (Table 3 ) and chemical composition of the organic residues (Table 2), especially $\mathrm{Ca}, \mathrm{Mg}, \mathrm{K}$ and/or $\mathrm{Na}$. The higher these constituents were, the higher the soil $\mathrm{pH}$ resulted following their incubation with the soils.
The generally lower soil $\mathrm{pH}$ in soil containing $360 \mathrm{~kg} \mathrm{~S} / \mathrm{ha}$ implies that oxidation of larger quantities of sulphur led to production of more acidity, all of which could not be neutralised by the residues. The chemical equation for the contribution of $\mathrm{S}$ to soil acidity is; 
Majule and Omolo - The performance of maize crop during acid amelioration ...

$\mathrm{S}+4 \mathrm{H}_{2} \mathrm{O}=\mathrm{SO}^{2-}+6 \mathrm{e}+8 \mathrm{H}+\log \mathrm{K}=-35$

\section{Effects of elemental sulphur on maize performance}

Results of the plant height, shoot and root and dry matter yields, as affected by different levels of sulphur without residue additions are presented in Table 4. Increasing levels of sulphur led to significant increases/decreases $(\mathrm{P}<0.05)$ in maize performance. Mean plant height was lowest where the level of sulphur was 0 or $360 \mathrm{~kg} \mathrm{~S} / \mathrm{ha}$, while it was highest when the sulphur level was $36 \mathrm{~kg} \mathrm{~S} / \mathrm{ha}$. Shoot and root dry matter yields showed trends similar to those of plant height. The dry matter yields were lowest where the level of sulphur was 0 and $360 \mathrm{~kg} \mathrm{~S} / \mathrm{ha}$ but highest where soil sulphur level was 36 and $72 \mathrm{~kg}$ S/ha.

Table 4: $\quad$ Effects of different levels of sulphur on maize performance in a Luvic arenosol after 30 days

\begin{tabular}{llll}
\hline & \multicolumn{3}{c}{ Dry matter yields (g/pot) } \\
\cline { 2 - 4 } Treatment & Height $(\mathbf{c m})$ & \multicolumn{1}{c}{ Shoot } & \multicolumn{1}{c}{ Root } \\
\hline S0 & $42.90 \mathrm{c}$ & $0.65 \mathrm{c}$ & $0.60 \mathrm{ab}$ \\
S36 & $49.28 \mathrm{a}$ & $0.73 \mathrm{~b}$ & $0.69 \mathrm{ab}$ \\
S72 & $45.87 \mathrm{~b}$ & $0.76 \mathrm{a}$ & $0.78 \mathrm{a}$ \\
S360 & $43.17 \mathrm{c}$ & $0.66 \mathrm{c}$ & $0.51 \mathrm{~b}$ \\
& & & \\
Average & 45.31 & 0.70 & 0.65 \\
Lsd $(0.05)$ & 2.25 & 0.02 & 0.18 \\
CV \% & 2.48 & 2.65 & 13.79 \\
\hline
\end{tabular}

* Means with same letter within a column are not significantly different at $\mathrm{P} \leq 0.05$.

The poor maize performance under the soil where sulphur was not added may be attributed to the low level of sulphur as a plant nutrient. Thus, addition of sulphur at 36 or $72 \mathrm{~kg} \mathrm{~S} /$ ha improved the available sulphur levels in the soil, resulting in higher dry matter yields. On the other hand, the lower yields and plant height at $360 \mathrm{~kg} \mathrm{~S} / \mathrm{ha}$ may be due to high soil acidity developed. Upon oxidation of the sulphur in the soil, soil $\mathrm{pH}$ fell to nearly 4.0 . This is a very high level of acidity which the maize plants could not tolerate and thus resulting in poor growth.

\section{Effects of organic residues and sulphur on growth of maize crop}

With the case of wild spikenard and sulphur additions (Table 5), there was no inconsistence in terms of maize plant heights. However, a significant difference was observed with the application of 36 $\mathrm{kgS} /$ ha together with the residue. Similar response was also observed for plants shoot and root dry weights. For this organic residue source, average plant height, shoot and root dry weights were the lowest.

With the case of cordia residue source (Table 5), plant height differed significantly $(\mathrm{P}<0.05)$ and was the highest with the application of crop residue alone without elemental sulphur. Generally, maize performance interms of plant height, shoot and root dry weight was significantly $(\mathrm{P}<0.05)$ higher than that observed for wild spikenard (Table 5). The better maize performance following incorporation of organic residues implies that the organic residues improved soil chemical conditions and therefore improved maize performance. Response of maize plant to sulphur and cowpea residue application is also shown in Table 5. Response of maize plant to treatments followed a similar pattern similar to other residue sources. The better maize performance with the case of pigeonpea (Table 5) implies a higher degree of amelioration of soil $\mathrm{pH}$, which, in turn, indicates a higher alkalinity in pigeon peas. 
Table 5. Effects of organic residues sources incorporated in soil containing different level of sulphur on maize plant heights and dry matter yields

\begin{tabular}{|c|c|c|c|c|c|c|c|c|c|c|c|}
\hline \multirow[t]{2}{*}{ Treat } & \multicolumn{3}{|c|}{ Plant growth parameter } & \multirow[t]{2}{*}{ Treat } & \multicolumn{3}{|c|}{ Plant growth parameter } & \multirow[t]{2}{*}{ Treat } & \multicolumn{3}{|c|}{ Plant growth parameter } \\
\hline & Height $^{\mathrm{P}}$ & Shoot $^{2}$ & $\operatorname{Root}^{3}$ & & Height & Shoot & Root & & Height & Shoot & Root \\
\hline S0PP & $69.37 b$ & $2.08 \mathrm{a}$ & $0.97 b$ & S0WS & $44.58 \mathrm{a}$ & $0.77 b$ & $0.60 \mathrm{a}$ & SOCR & $66.33 a$ & $1.76 \mathrm{a}$ & $0.96 b$ \\
\hline S36PP & $65.08 \mathrm{c}$ & $1.93 b$ & $0.72 \mathrm{~d}$ & S36WS & $41.58 b$ & $0.67 \mathrm{c}$ & $0.46 \mathrm{~d}$ & S36CR & $61.55 b$ & $1.62 \mathrm{a}$ & $0.85 \mathrm{c}$ \\
\hline S72PP & $71.25 \mathrm{a}$ & $2.06 \mathrm{a}$ & $0.86 \mathrm{c}$ & S72WS & $44.33 \mathrm{a}$ & $0.92 \mathrm{a}$ & $0.55 b$ & S72CR & $64.92 \mathrm{a}$ & $1.68 \mathrm{a}$ & $1.08 \mathrm{a}$ \\
\hline S360PP & $70.33 \mathrm{ab}$ & $2.07 \mathrm{a}$ & $1.10 \mathrm{a}$ & S360WS & $44.25 \mathrm{a}$ & $0.81 b$ & $0.54 \mathrm{c}$ & S360CR & $65.83 \mathrm{a}$ & $1.77 \mathrm{a}$ & $0.97 b$ \\
\hline $\begin{array}{l}\text { Mean } \\
\text { Lsd }\end{array}$ & 69.01 & 2.03 & 0.91 & Mean & 43.67 & 0.79 & 0.54 & Mean & 64.66 & 1.71 & 0.97 \\
\hline (0.05) & 1.37 & 0.02 & 0.09 & $\operatorname{Lsd}_{(0.05)}$ & 2.21 & 0.06 & 0.01 & $\begin{array}{l}\text { Lsd } \\
(0.05)\end{array}$ & 2.31 & 0.14 & 0.06 \\
\hline$C V \%$ & 1.00 & 0.87 & 4.83 & $\mathrm{CV} \%$ & 2.53 & 3.09 & 3.29 & $C V \%$ & 1.79 & 4.14 & 3.19 \\
\hline
\end{tabular}

${ }^{1}$ Plant height expressed in $\mathrm{cm}$

${ }^{2}$ Shoot dry weight expressed in $\mathrm{g} / \mathrm{pot}$

${ }^{3}$ Root dry weight expressed in g/pot

The results in this study are in agreement with those obtained by Tang and Yu (1999) who observed that plant residues incorporated in acidic soils increased soil $\mathrm{pH}$ and that the magnitude of the increase was positively correlated with the concentration of excess cations that is potential alkalinity, in the plant materials. Similar results were also reported by Majule (1999) and Omollo (2003). Thus a potential exists for the utilization of organic materials with high alkalinity for purposes of ameliorating soil acidity.

\section{CONCLUSIONS}

Increased levels of sulphur in the soils of Mtwara as a result of continual dusting of cashewnut trees with elemental sulphur has been found to reduce the growth and dry matter yields of maize in the cashew-maize cropping system. This reduction in maize growth and hence yields was due to intense acidity developed because sulphur underwent oxidation in soil with consequent production of $\mathrm{H}^{+}$in soils which reduced soil $\mathrm{pH}$. Pigeonpea and cordia residues, which had highest alkalinity values, resulted in a higher level of amelioration of soil acidity compared to senescent cowpea and wild spikenard, which had lowest alkalinity values. More research is required for the purpose of identification of potential organic residues sources that will ameliorate acidity and improve soil fertility. However, the knowledge on organic residue management should be extended to farmers if soil productivity in the cashew maize cropping system is to be increased and sustained.

\section{ACKNOWLEDGEMENTS}

Authors would like to express their sincere gratitude to Sokoine University of Agriculture (SUA) and the Institute of Resource Assessment (IRA) of the University of Dar es Salaam for facilitating this study. We are also grateful to the Norwegian Agency for Development Cooperation (NORAD) and the Rockefeller Foundation for funding this study. Further, we wish to extend our thanks to the staff of Naliendele Agricultural Research Institute (NARI) and also Department of Soil Science, SUA who assisted in both fieldwork and laboratory analysis.

\section{REFERENCES}

Bray RH and Kurtz LT 1945 Determination of total, organic and available forms of phosphorus in soils. Soil Sci. 59: 39 45. 
Majule and Omolo - The performance of maize crop during acid amelioration ...

Bremner JM and Mulvaney CS 1982 Total nitrogen. In: Method of Soil Analysis Part 2. Agronomy Monograph No. 9. (Edited by Page, A.L., Miller, R.H. and Keeney, P.R.). American Society of Agronomy Inc., Madison, Wisconsin. pp. 149 - 157.

EUROCONSULT 1989 Agricultural Compendium for Rural Development in the Tropics and Subtropics. Elsevier Science Publishers, Amsterdam. 740pp.

FAO - UNESCO - ISRIC 1988 FAO/Unesco Soil Map of the World Revised Legend. World Soil Resources Report 60. FAO. Rome. 138pp.

Gee GW and Bauder JW 1986 Particle size analysis. In: Method of Soil Analysis Part 1. Agronomy Monograph No. 9. (Edited by Klute, A.). American Society of Agronomy Inc., Madison, Wisconsin. pp. $383-409$.

Gomez KA and Gomez AA 1984 Statistical Procedures for Agricultural Research. John Wiley and Sons Inc., New York. 680pp.

Jones BJJR and Case VW 1990 Sampling, handling and analysing plant tissue samples. In: Soil Testing and Plant Analysis $3^{\text {rd }}$ edition. (Edited by Westerman, R.L.). Soil Science Society of America Inc., Madison, Wisocnsin. pp. $389-427$.

Landon JR 1991 Booker Tropical Soil Manual. A Handbook for soil survey and agricultural land evaluation in the tropics and subtropics. Longman, New York. 450pp.

MacLean EO 1982 Aluminium. In: Method of Soil Analysis Part 2. Agronomy Monograph No. 9. (Edited by Page, A.L., Miller, R.H. and Keeney, P.R.) American Society of Agronomy Inc., Madison, Wisconsin. pp. 221 - 223.

Majule AE, Toper CP and Nortcliff S 1997 The environmental effect of dusting cashew (Anarcadium occidentale L) trees with sulphur in southern Tanzania. Trop. Agric. J. (Trinidad) 74:25-33.

Majule AE 1999 The Effects of organic residues and elemental sulphur additions to soils of southern Tanzania. $P h D$ Thesis. Reading University. UK. 238pp.

Majule AE 2001 The role of organic residues in conserving soil fertility of cashew producing areas of south Tanzania. J. Geogr. Assoc. Tanz.. Volume 29:11-38.

Martin PJ, Topper RA, Boma F, De waal D, Haries H, Kasuga LJ, Katanila N, Kikoka LP, Lamboll R, Madison A, Majule AE, Masawe PA, Millanzi KJ, Nathaniels NQ, Shomari SH, Sijoana ME and Stathers T 1997 Cashewnut production in Tanzania: Constraints and progress through integrated crop management. Crop Protection 16: 6 14.

Murphy J and Rilley JP 1962 A modified single solution method for determination of phosphate in natural water. Anal. Chim. Acta 27: 31 - 36.

Nelson DW and Sommers LW 1982 Organic carbon In: Method of Soil Analysis Part 2. Agronomy Monograph No. 9. (Edited by Page, A.L., Miller, R.H. and Keeney, P.R.). American Society of Agronomy Inc., Madison, Wisconsin. pp. 561 - 573.

Ngatunga EL, Cools N, Dondeyne S, Deckers JA and Merckx R 2001 Buffering capacity of cashew soils in South Eastern Tanzania. Soil Use and Management 17: 155 - 162.

Omollo JO 2003 Effect of organic residues in ameliorating sulphur induced acidity on maize growth in cashewnut growing Soils of Mtwara, Tanzania. M.Sc. Dissertation. Sokoine University of Agriculture, Morogoro, Tanzania. 89pp.

Pierre WH and Banwart WL 1973 Excess base and excess base/nitrogen ratios of various crop species and plant parts. Agron. J. 65: 91 - 96.

Pocknee S and Sumner ME 1997 Cation and nitrogen contents of organic matter determine its soil liming potential. Soil Sci. Soc. Amer. J. 61: 86 - 92.

Rowell DL 1994 Soil Sciences: Methods and Applications. Longman, London. England. 359pp. 
Sakala MG 1998 The Effect of Incorporating Plant Residues on Soil Acidity in The Management of Tropical Soils. PhD Thesis, Reading University, UK. 220pp.

Smith DN, King WJ, Topper CP, Boma F and Copper JF 1995 Alternative techniques for the application of sulphur to control powdery mildew caused by fungus Oidium anarcadii in Tanzania. Crop Protec. 14 (7):550-560.

Tang C and Yu, Q 1999 Impact of chemical composition of legume residues and initial soil $\mathrm{pH}$ on $\mathrm{pH}$ change of a soil after residue incorporation. Plant and Soil 215: 29 - 38.
Thomas GW 1982 Exchangeable cations. In: Method of Soil Analysis Part 2. Agronomy Monograph No. 9. (Edited by Page, A.L., Miller, R.H. and Keeney, P.R.). American Society of Agronomy Inc., Madison, Wisconsin. pp. 159 - 164.

Yan F and Schurbert S 2000 Soil pH changes after application of plant shoot material of faba bean and wheat. Plant and Soil 220: 287-297.

Zall DM, Fisher D and Gerner MQ 1956 Photometric determination of chloride in water. Anal. Chem. 28:1665-1668. 